\begin{abstract}
Women in the sciences who earn PhDs are less likely than their male counterparts to pursue tenure-track positions at research universities. Moreover, among those who become STEM researchers, men have been found to publish more than women. These patterns raise questions about when sex differences in publication begin. Using data from a survey of doctoral students at one large institution, this study finds that men submitted and published more scholarly works than did women across many fields, with differences largest in natural/biological sciences and engineering. Potential contributing factors are considered, including sex differences in faculty support, assistantships, family responsibilities and career goals.

Keywords: sex, gender, publications, STEM, career, research, doctoral students, graduate education
\end{abstract}


RUNNING HEAD: SEX DIFFERENCES IN DOCTORAL PUBLICATIONS

\section{Sex Differences in Doctoral Student Publication Rates}

A recent study of bibliometric data from across the globe found 1.9 times as many articles published by men than by women (Larivière, Ni, Gingras, Cronin, and Sugimoto, 2013). This pattern may be largely due to the fact that more men are established, full-time scholars in many fields. For example, within the top 100 U.S. universities, women comprise only $9-16 \%$ of tenure-track faculty in many math-intensive fields (Ceci \& Williams, 2001).

Larivière et al. (2013) also noted that publication gaps by sex are particularly large in fields requiring large research expenditures and suggested that inequitable funding practices may be a factor in these publication gaps. Ceci and Williams (2011) reviewed data from several prior studies and found little evidence of biased grant and article review processes, but they did note that men in academia have more resources, including time for conducting research, as women are more often in part-time and teaching-intensive positions and are disproportionately affected by family responsibilities.

General analyses of bibliometric databases, such as that conducted by Larivière et al. (2013), can offer useful, birds-eye estimates of the numbers of publications authored by men and women. However, such analyses cannot directly compare rates of publication by $\operatorname{sex}^{1}$, as they do not identify the full population of all potential authors. ${ }^{2}$ In a rare comparison of publication rates, Milesi, Brown, Hawkley, Dropkin, and Schneider (2014) found that, in a national sample of STEM researchers, men published over $25 \%$ more journal articles than did women (with the difference slightly less among those with National Science Foundation funding). However, the

${ }^{1}$ Given the binary nature of the comparisons in this study, we use the term "sex" instead of "gender" when comparing men and women, but we use "gender" when discussing broader issues.

${ }^{2}$ Additionally, as Larivière et al. (2013) note, large-scale, bibliometric analyses are prone to some error when relying on authors' names to determine the sex of the author. 


\section{RUNNING HEAD: SEX DIFFERENCES IN DOCTORAL PUBLICATIONS}

national sample consisted of only $29 \%$ women, raising the questions of whether this difference holds in fields with gender parity and when such differences begin. In a recent study focused on biology, which now has over 50\% female Ph.D. graduates, male first-year Ph.D. students spent fewer hours on research yet published $15 \%$ more journal articles than their female peers for every 100 hours invested (Feldon, Peugh, Maher, Roksa, \& Tofel-Grehl, 2017).

These studies raise questions about how men's and women's career paths begin and diverge, and whether differences at the starting gate, such as those found by Feldon et al. (2017) in biology, occur across all academic fields. We do know that, across fields, women are less likely than men to attend the most prestigious doctoral programs (Weeden, Thébaud, \& Gelbgiser, 2017), and so this may account for some differences in publication and career trajectories. However, we do not know whether male and female researchers in the same academic stage, field, and institution, publish at similar rates, and whether differences appear even at the earliest career stage - graduate school. If so, these differences might relate to a later divergence in career paths, including fewer female Ph.D. graduates in the sciences pursuing tenure-track positions than their male counterparts (Canizares, 2009).

This study addresses the following questions:

1) Among doctoral students within the same institution, do the number of scholarly works submitted for publication, first-authored and published differ between women and men?

2) How do such differences vary by field?

\section{Method}

This study uses 1,285 responses from a survey given to recent Ph.D. graduates from one BigTen institution. The survey assessed satisfaction with many program components (e.g., advising, coursework, financial support, etc.) and also asked about the number of "research articles, 


\section{RUNNING HEAD: SEX DIFFERENCES IN DOCTORAL PUBLICATIONS}

chapters, and other scholarly works" submitted during doctoral study. Follow-up questions asked about the number of first- or solo-authored submissions, as well as the number of submissions that were accepted or published. Five additional program satisfaction and support items were examined that might shed light on reasons for the publication disparities, along with seven additional questions pertaining to program supports and obstacles that were administered to only a subset of students (with $n$ 's ranging from 546 to 734). A question about career goals, administered to only 523 of the 1285 students, was also considered.

The university assigned its 90 doctoral programs into five broad groups for assessment purposes. $^{3}$ To test for significant sex differences in publications within the five program groups, multilevel Poisson regression models were used (appropriate for outcomes consisting of counts). Additionally, $t$-tests were used to examine differences in men's and women's responses to the 12 survey questions regarding program satisfaction, supports and obstacles (with adjustments made for multiple comparisons). Additional Poisson regression models were also used to examine whether the 12 survey variables predicted the number of publication submissions. In keeping with Educational Researcher's "Brief" format, details of survey and analysis methods are included in the online Appendix, including mean differences of potential explanatory variables by sex and program group (Tables A2-A4), Poisson regression results (Tables A5-A7) and correlations among the survey variables (Tables A8-A9).

\footnotetext{
${ }^{3}$ Table A1 contains enrollments by sex in each program and group. Although the group names are not mutually exclusive and the clusters may appear to defy conventions in some ways, these categories were created to reflect the structure of the university (e.g., where physics and computer science reside in the College of Engineering, for example) and to allow for the programs considered most similar within the university to be clustered together for review purposes. Given this study's focus on gender, it is helpful that physics, mathematics, engineering, and computer science are grouped together, as these tend to be the most maledominated STEM fields (Schneider, Milesi, Perez-Felkner, Brown, \& Gutin, 2015). Hence, this study uses the original groupings created by the university.
} 
RUNNING HEAD: SEX DIFFERENCES IN DOCTORAL PUBLICATIONS

\section{Results}

\section{Publication Rates by Sex}

As shown in Table 1, men submitted an average of 5.9 manuscripts for publication (3.7 as first or solo author), in contrast with women's report of 3.7 publications submitted (2.2 as first or solo author). The number of submissions that were published or accepted also differed significantly, with an average of 4.9 for men and 2.9 for women.

Differences were larger in some fields than others. In the engineering and physical sciences, men submitted an average of 7.2 publications, compared with 5.5 among women $(d=.40)$, and in the natural and biological sciences, men submitted an average of 5.3 publications in comparison with 3.8 among women $(d=.49)$. Differences in humanities/arts and applied health/social sciences were also significant and followed a similar, but less marked pattern favoring men. (See Figure 1 for distributions by sex and program group.)

However, there were no significant sex differences in publications in the education and professional programs. These results are encouraging in comparison with earlier Educational Researcher articles that reported a severe under-representation of female authors of education research (Lipman-Blumen, Stivers, Tickamyer \& Brainard, 1975; Lockheed \& Stein, 1980). This shift may reflect changes in the composition and publishing expectations of education researchers over the past several decades.

\section{Additional Survey Data by Sex}

Several other variables from the doctoral survey could shed light on reasons for these patterns in publication rates. First, overall, men tended to have slightly higher satisfaction with key components of their doctoral experience than did women, including their relationship with their advisor $(d=.19)$ and career preparation $(d=.28)$ (Table A2). These differences were 


\section{RUNNING HEAD: SEX DIFFERENCES IN DOCTORAL PUBLICATIONS}

slightly larger in at least some STEM fields and were significant predictors of publication submissions in the regression analysis (Table A5, Model 3). Men were also slightly more satisfied than women with program collegiality $(d=.14)$, but this difference was only significant within education and professional programs, and collegiality was not a significant predictor of publication submissions in the regression models (and was thus removed).

An examination of assistantships by sex (Table A2) revealed that, overall, men (85\%) were slightly more likely than women (80\%) to report being a research assistant (RA) at some point in their program. However, this difference was inconsistent across program groups and not significant within any of the five groups after Bonferroni correction. Similarly, women (82\%) were more likely than men (76\%) to serve as a teaching assistant (TA), and to report that teaching responsibilities were an obstacle to program progress $(d=.26)$, but sex differences within program groups were not significant. The regression analysis revealed that RAships were a strong, positive predictor of publication submissions (with RAs submitting $70 \%$ more manuscripts than non-RAs), while TAs and those who reported that teaching responsibilities were an obstacle to program progress submitted about $10 \%$ fewer publications than did other students.

Supplemental questions asked a subsample of students about faculty support for their research and chosen career paths (Table A3). Overall, men were more likely than women to report that faculty encouraged their publication of scholarly work $(d=.37)$, but women were as likely as men to report that their advisor supported them in their chosen career path. Additionally, women were more likely than men to report that family obligations $(d=.16)$, work/financial commitments $(d=.32)$, and faculty availability $(d=.26)$ hindered their progress, although these patterns were not consistent across program groups, nor significant within any 


\section{RUNNING HEAD: SEX DIFFERENCES IN DOCTORAL PUBLICATIONS}

group after Bonferroni correction. Women were also more likely than men to say that a biased program climate was an obstacle for them $(d=.47)$, although this was less of an obstacle for women than other factors, with only $6 \%$ of women (versus $2 \%$ of men) saying this was a "major obstacle." In comparison, $14 \%$ of women cited family obligations ( $8 \%$ of men), $20 \%$ cited work/financial commitments ( $10 \%$ of men), $15 \%$ cited teaching responsibilities ( $8 \%$ of men), and $11 \%$ (6\% of men) cited faculty availability as "major obstacles" to program progress. In the regression analyses conducted with the subsample who answered all of these survey questions ( $n$ $=495$ ), faculty encouragement of publication was a significant, positive predictor of submissions for publication, while family obligations and lack of faculty availability was a negative predictor (Table A7). Student reports of work/financial obligations or program climate hindering their progress did not significantly relate to their publication submissions.

Still, overall, the main regression analysis, which included program satisfaction and RA/TA variables for the full analytic sample $(n=1285)$, left the majority of the sex difference in publication submissions unexplained (as described further in Table A5, Note 3). The same was true with the supplementary regression analysis containing additional data on program supports and obstacles collected from a subsample of the analytic sample $(n=495$; see Table A7).

Survey data on students" "primary career goal" were also collected from a subsample of students (Table A4). Significantly more men than women hoped to obtain a research-intensive faculty position ( $34 \%$ versus $25 \%$ ) or a private sector position ( $27 \%$ versus $12 \%)$. Hence, perhaps men in this study pursued more publication opportunities because they prioritized jobs that require a strong research record. On the other hand, given that career goals were reported after doctoral program completion, men's stronger publication records might have contributed to sex differences in reported career goals. 
RUNNING HEAD: SEX DIFFERENCES IN DOCTORAL PUBLICATIONS

\section{Discussion}

The men in this study submitted and published substantially more scholarly works than did their female peers. It is noteworthy that this pattern occurred in both the heavily male-dominated engineering and physical sciences group as well as in other program groups not dominated by men, including the natural and biological sciences, humanities and creative arts, and social sciences and applied health. A dozen additional survey items were used to explore why these patterns may have occurred, including whether men felt more supported in their programs than did women.

Men rated their relationship with advisor, career preparation and faculty support for research higher than did their female peers, and satisfaction on these items predicted publication submissions in the regression models. The sex differences in these variables align with previous studies suggesting that male doctoral students may receive more research mentoring from their advisors in science (Fox, 2000; Nolan, Buckner, Marzabdi \& Kuck, 2008) and other fields (Seagram, Gould \& Pyke, 1998). Although sex differences in assistantships were not consistent across programs, research assistantships were a strong predictor of publication submissions.

Although few students in this study reported that a biased program climate was a "major obstacle" to their progress, more women than men - particularly in engineering and social sciences/applied health — reported that a biased climate was at least a minor obstacle, suggesting that another factor could be the culture of STEM programs during graduate school. This seems to fit with disparities in faculty encouragement noted above, as well as recent news and blog reports suggesting that women may be more likely than men to be relegated to managerial tasks in the lab, and viewed in sexual instead of professional terms (Greenberg, 2015; Jarreau, 2016). However, student reports of a hindering program climate did not relate to publication 


\section{RUNNING HEAD: SEX DIFFERENCES IN DOCTORAL PUBLICATIONS}

submissions in the supplementary regression analysis, yet the subsample available for that particular analysis was relatively small, and so this null finding should be interpreted with caution.

Ceci and Williams note that childcare issues affect women more than men. In this study family responsibilities were reported to be more of a hindrance for women than for men. Still, this difference was not large or consistent across program groups.

Overall, both the full-sample and sub-sample regression analyses that included all potential explanatory survey variables available in this study left the majority of the sex disparities in publication submissions within each program group unexplained. It could be that more sensitive variables are needed to detect the most relevant forms of doctoral program bias against women, and perhaps more focused examinations of specific programs would yield more clear results in terms of explaining publication disparities. However, it could also be that factors that go beyond faculty bias and traditional program supports should be considered, particularly given that publication disparities were substantial even in fields with gender parity.

For example, it is possible that even when women and men have similar opportunities to engage with research, male doctoral students may be more assertive when negotiating authorship. Additionally, as Martin (2015) argues, men may be more confident in their abilities and, therefore, more willing to submit their work for evaluation. This hypothesis is consistent with earlier findings by Sonnert and Holton (1995), suggesting that women who are STEM researchers may be more thorough and cautious in publishing their work than men. In fact, Sonnert and Holton wondered if this more cautious approach should be preferred over the push for larger numbers of publications. Still, if this were a driving force in these results, we might expect to see sex differences in first-authored submissions to be particularly large, and for the 


\section{RUNNING HEAD: SEX DIFFERENCES IN DOCTORAL PUBLICATIONS}

gap in submissions to be larger than the gap in accepted work. However, that is not the case, according to the data in Table 1.

Scholars have also found gender differences in career preferences and values (Ceci \& Williams, 2011; Eccles \& Wang, 2015). Although career preferences might seem unlikely to explain the patterns noted here (given that sex disparities in publishing persisted within fields and not just between them), men might more aggressively pursue publication during graduate school because they more often prioritize high occupational status and pay, in comparison with women's preference for working with, and helping others (Eccles \& Wang, 2015). It is striking that in this study, although women reported less faculty support for publication, they reported similar satisfaction as did men with support for their chosen career path. Moreover, the men were more likely than women to report that a research-intensive faculty position was their primary career goal. Hence, the women in this study may have viewed publications as less essential for their future careers than did the men.

Regardless of the cause, concerns remain about long-term disadvantages women face if they publish less than their male peers. Given that some potential factors explored here differed by sex in some disciplines but not others, and given that the various factors together left much of the sex gap in publications unexplained in the regression analyses, more focused studies within disciplines and across institutions are needed to further understand the mechanisms at work.

\section{Limitations}

One limitation of this study involves the relatively small sample sizes within some program groups, as well for the supplemental questions asked. Small sample sizes can lead to erroneous null findings (such as within the humanities and creative arts). To lessen this concern, marginally significant findings - i.e., those that became insignificant after Bonferroni 


\section{RUNNING HEAD: SEX DIFFERENCES IN DOCTORAL PUBLICATIONS}

correction - are noted (Tables A2-A3). Additionally, the percentages of men and women and the gendered publication patterns were similar in the various samples used in this study, lessening concerns about selection bias (details in Footnote A2).

Another limitation is that analyses of program groups might mask important differences among programs within the same program group, including differences in gender parity, publication norms, time-to-degree and other factors that could influence publication submissions. ${ }^{4}$ Further studies of gendered patterns within specific programs would complement the broader patterns reported here.

Perhaps the most important limitation of this study is its reliance on data from a single university. Although some might wonder if this university's programs are simply highly biased against women, this seems unlikely, as the survey data showed small or no sex differences in many areas of program satisfaction, including program collegiality and support for their chosen career path. Additionally, across the university's STEM departments, there are several thriving graduate organizations (e.g., GradSWE-A graduate student affiliate of Society for Women in Engineering) and supports (fellowships, conferences, retreats) targeting women in STEM. Although further research is needed to determine whether results are consistent at other research universities, it seems unlikely that the publication patterns favoring men in departments and colleges across this university, are unique to this institution.

\footnotetext{
${ }^{4}$ For example, the humanities/arts includes both philosophy (which is male dominated) and art history (which is female dominated). Given sample limitations, this study does not delve into differences between such fields, nor explore other field-specific issues, such as how the association of "brilliance" with many male-dominated fields (Meyer, Cimpian \& Leslie, 2015) might relate to field publication norms and the type of student attracted to such fields. Such work could be fruitful in future studies of sex differences in publication and career paths.
} 
RUNNING HEAD: SEX DIFFERENCES IN DOCTORAL PUBLICATIONS

\section{Implications}

These findings from a fairly typical, large R1 university point to a potentially important difference between men and women in doctoral programs - i.e., authorship of publications. If the findings in this study hold up at other institutions, this would suggest that, from the starting line, women — especially those in the natural/biological and engineering/physical sciences—may be given fewer opportunities to publish during graduate school, or perhaps are less wellpositioned or inclined to pursue such opportunities. Such patterns could lay the groundwork for divergent career trajectories and might help explain why women in the sciences are less likely than men to seek tenure-track positions, even after receiving their Ph.D. (Canizares, 2009).

Larger-scale studies are needed to determine the generalizability of these findings, as well as qualitative studies to further illuminate reasons behind these patterns, assuming they do persist. Such studies could inform the strategic targeting of interventions to ensure women benefit from doctoral study as much as men. These interventions could take various forms, including reducing women's TA responsibilities, increasing the availability of RA positions for women, assisting with family obligations, providing better training for faculty in mentoring of doctoral students (enhancing lab culture, encouraging women to submit their work, and modeling authorship negotiation skills), or increasing opportunities for women to experience scientific research as an inclusive, valuable endeavor. 
RUNNING HEAD: SEX DIFFERENCES IN DOCTORAL PUBLICATIONS

\section{References}

Ceci, S. J., \& Williams, W. M. (2011). Understanding current causes of women's underrepresentation in science. Proceedings of the National Academy of Sciences, 108(8), 3157-3162.

Canizares, C. R. (2009). Gender differences at critical transitions in the careers of science, engineering and mathematics faculty. In Memoriam, 35.

Eccles, J. S., \& Wang, M. (2016). What motivates females and males to pursue careers in mathematics and science? International Journal of Behavioral Development, 40(2), 100106.

Feldon, D.F., Peugh, J., Maher, M. A., Roksa, J., \& Tofel-Grehl, C. (2017). Time-to-credit gender inequities of first-year Ph.D. students in the biological sciences. CBE-Life Sciences Education, 16(1), doi: 10.1187/cbe.16-08-0237CBE Life Sci Educ vol. 16 no. 1 ar4.

Fox, M. F., (2001). Women, science and academia: Graduate education and careers. Gender \& Society, 15(5), 654-666.

Greenberg, A. (2015, June 10). A Nobel scientist just made a breathtakingly sexist speech at international conference. Time. Retrieved from http://time.com/3915617/women-sciencetim-hunt-nobel-sexist/

Jarreau, P. B. (2016, March 8). Being female in science. Retrieved from http://www.fromthelabbench.com/from-the-lab-bench-science-blog/2016/3/8/being-woman

Larivière, V., Ni, C. Q., Gingras, Y., \& Cronin, B., \& Sugimoto, C. R. (2013). Global gender disparities in science. Nature, 504(7,479), 211-213.

Lipman-Blumen, J., Stivers, P. E., Tickamyer, A. R., \& Brainard, S. (1975). Participation of women in the educational research community. Educational Researcher, 4(9), 5-14. 
RUNNING HEAD: SEX DIFFERENCES IN DOCTORAL PUBLICATIONS

Lockheed, M. E., \& Stein, S. L. (1980). The status of women's research in educational publications. Educational Researcher, 9(2), 11-15.

Martin, G. (2015). Addressing the underrepresentation of women in mathematics conferences. Science Open. Retrieved from https://www.scienceopen.com/document?vid=8c9bb4fc7e38-4a5e-8624-d0e2706bdce4.

Meyer, M., Cimpian, A., \& Leslie, S. J. (2015). Women are underrepresented in fields where success is believed to require brilliance. Frontiers in Psychology, 6, 235. doi: 10.3389/fpsyg.2015.00235.

Milesi, C., Brown, K. L., Hawkley, L., Dropkin, E., Schneider, B. L. (2014). Charting the impact of federal spending for education research: A bibliometric approach. Educational Researcher, 43(7), 361-370.

Nolan, S. A., Buckner, J. P., Marzabadi, C. H., \& Kuck, V. J. (2008). Training and mentoring of chemists: A study of gender disparity. Sex Roles, 58 (3-4), 235-250.

Seagram, B. C., Gould, J. \& Pyke, S. W. (1998). An investigation of gender and other variables on time to completion of doctoral degrees. Research in Higher Education, 39(3), 319-335.

Schneider, B., Milesi, C., Perez-Felkner, L., Brown, K., \& Gutin, I. (2015, July). Does the gender gap in STEM majors vary by field and institutional selectivity? Teachers College Record.

Sonnert, G. \& Holton, G. J. (1995). Who succeeds in science? The gender dimension. New Brunswick, New Jersey: Rutgers University Press.

Weeden, K. A., Thébaud, S., Gelbgiser, D. (2017). Degrees of difference: Gender segregation of U.S. doctorates by field and program prestige. Sociological Science, (4), 123-150. 
RUNNING HEAD: SEX DIFFERENCES IN DOCTORAL PUBLICATIONS

Table 1

Doctoral Student Publications by Sex and Program Group

\begin{tabular}{|c|c|c|c|c|c|c|c|}
\hline \multirow[t]{2}{*}{ Program Group } & & \multicolumn{2}{|c|}{$\begin{array}{l}\text { Total Publications } \\
\text { Submitted }\end{array}$} & \multicolumn{2}{|c|}{$\begin{array}{c}\text { Total Publications } \\
\text { Submitted as First } \\
\text { Author }\end{array}$} & \multicolumn{2}{|c|}{$\begin{array}{l}\text { Total Publications } \\
\text { Accepted or } \\
\text { Published }\end{array}$} \\
\hline & & Men & Women & Men & Women & Men & Women \\
\hline \multirow{4}{*}{$\begin{array}{l}\text { Social Sciences } \\
\text { and Applied } \\
\text { Health }^{\text {a }}\end{array}$} & Mean & 4.45 & 3.68 & 2.72 & 1.90 & 3.45 & 2.95 \\
\hline & SE & 0.44 & 0.28 & 0.29 & 0.17 & 0.39 & 0.24 \\
\hline & & 109 & 99 & 109 & 99 & 109 & 99 \\
\hline & Effect Size $(d)$ & \multicolumn{2}{|c|}{$0.20 * *$} & \multicolumn{2}{|c|}{$0.33 * * *$} & \multicolumn{2}{|c|}{0.15} \\
\hline \multirow{4}{*}{$\begin{array}{l}\text { Natural and } \\
\text { Biological } \\
\text { Sciences a }\end{array}$} & Mean & 5.32 & 3.78 & 3.23 & 2.47 & 4.29 & 3.01 \\
\hline & SE & 0.30 & 0.34 & 0.21 & 0.30 & 0.30 & 0.28 \\
\hline & & 106 & 87 & 106 & 87 & 106 & 87 \\
\hline & Effect Size $(d)$ & \multicolumn{2}{|c|}{$0.49 * * *$} & \multicolumn{2}{|c|}{$0.31 * *$} & \multicolumn{2}{|c|}{$0.45^{* * *}$} \\
\hline \multirow{4}{*}{$\begin{array}{l}\text { Engineering and } \\
\text { Physical } \\
\text { Sciences }{ }^{\text {a }}\end{array}$} & Mean & 7.21 & 5.47 & 4.51 & 3.27 & 6.16 & 4.46 \\
\hline & SE & 0.21 & 0.36 & 0.16 & 0.24 & 0.19 & 0.33 \\
\hline & & 469 & 112 & 469 & 112 & 469 & 112 \\
\hline & Effect Size $(d)$ & \multicolumn{2}{|c|}{$0.40^{* * *}$} & \multicolumn{2}{|c|}{$0.37 * * *$} & \multicolumn{2}{|c|}{$0.42 * * *$} \\
\hline \multirow{4}{*}{$\begin{array}{l}\text { Education and } \\
\text { Professional } \\
\text { Programs }^{\text {a }}\end{array}$} & Mean & 2.83 & 3.03 & 1.70 & 1.67 & 2.03 & 2.30 \\
\hline & SE & 0.46 & 0.33 & 0.35 & 0.23 & 0.38 & 0.27 \\
\hline & & 66 & 100 & 66 & 100 & 66 & 100 \\
\hline & Effect Size $(d)$ & \multicolumn{2}{|c|}{-0.06} & \multicolumn{2}{|c|}{0.01} & \multicolumn{2}{|c|}{-0.09} \\
\hline \multirow{4}{*}{$\begin{array}{l}\text { Humanities and } \\
\text { Creative Arts }{ }^{\text {a }}\end{array}$} & Mean & 2.98 & 1.72 & 2.37 & 1.53 & 2.27 & 1.36 \\
\hline & SE & 0.55 & 0.25 & 0.53 & 0.23 & 0.40 & 0.23 \\
\hline & $n$ & 62 & 75 & 62 & 75 & 62 & 75 \\
\hline & Effect Size $(d)$ & \multicolumn{2}{|c|}{$0.38^{* * *}$} & \multicolumn{2}{|c|}{$0.26^{* * *}$} & \multicolumn{2}{|c|}{$0.35^{* * *}$} \\
\hline \multirow{4}{*}{ Total $^{b}$} & Mean & 5.92 & 3.67 & 3.71 & 2.22 & 4.92 & 2.93 \\
\hline & SE & 0.16 & 0.16 & 0.12 & 0.11 & 0.15 & 0.13 \\
\hline & $n$ & 812 & 473 & 812 & 473 & 812 & 473 \\
\hline & Effect Size $(d)$ & \multicolumn{2}{|c|}{$0.54 * * *$} & \multicolumn{2}{|c|}{$0.48^{* * *}$} & \multicolumn{2}{|c|}{$0.53^{* * *}$} \\
\hline
\end{tabular}

${ }^{a}$ Significance levels by program group refer to post hoc chi-squared tests on the Model 2 coefficients found in the Poisson regression models shown in Tables A5 and A6 ( $d f=1 ; \mathrm{H}_{0}$ : Male + Male*ProgramGroup $=0) . p$-values were corrected using a Benjamini-Hochberg correction for multiple comparisons (15 comparisons).

$* p<.05, * * p<.01, * * * p<.001$ 
Figure 1

Number of Publications Submitted by Sex and Program Group
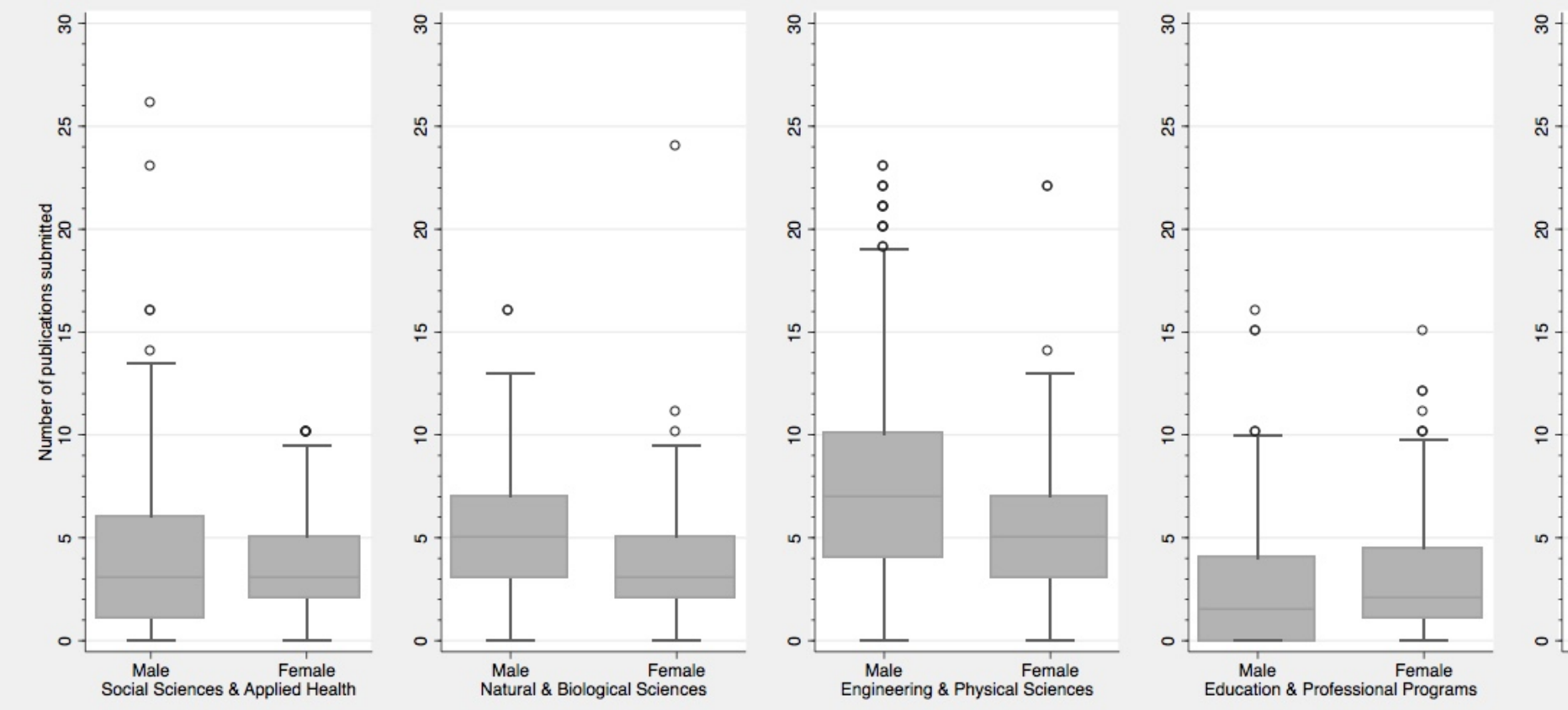


\section{Online Appendix}

\section{Data Collection and Analysis}

The surveys used in this study were administered to doctoral students at a Big-Ten university over two years (2013-2015), as part of its assessment of doctoral programs. Students were asked dozens of questions pertaining to their doctoral program experiences, including advising, collegiality, support and research. Most items used a 5-point Likert scale. Each survey was linked to students' institutional demographic data, including self-reported sex, which had been collected using binary male and female categories. ${ }^{5}$ Table A1 contains sample sizes by sex for each doctoral program.

In 2013-2014, students who completed their Ph.Ds were surveyed one year postgraduation. However, in 2015, the survey was revised and became a doctoral exit requirement. This study uses data from the post-graduation survey (total $n=621$ ) and the doctoral exit survey (total $n=768$ ), which both contained questions regarding publications during doctoral study. While the post-graduation survey response rate was relatively low (about 35\%), the response rate for the mandatory exit survey was $100 \%$, with $96 \%$ completing the questions of interest

\footnotetext{
5 The university recently changed this practice and now asks students to identify their gender from a broader set of categories.
} 
regarding publication. ${ }^{67}$ After the removal of students who were missing data from any of the three publication questions or any of the five main program satisfaction and employment questions (from Table A2), the final analytic sample contained 1285 students.

Three publication variables. The following three survey items were the primary focus of the analysis: ${ }^{8}$

1. While pursuing your doctoral studies, how many research articles, chapters, and other scholarly works did you submit for publication (as an author or a co-author)? [dropdown: None; $1 ; 2 ; 3 ; 4 ; 5 ; 6 ; 7 ; 8 ; 9 ; 10 ; 11 ; 12 ; 13 ; 14 ; 15 ; 16 ; 17 ; 18 ; 19 ; 20{\text { or more }]^{9}}^{9}$

${ }^{6}$ To examine the potential impact of the relatively low response rate for the post-graduation survey, we compared demographics of that sample versus the exit survey sample. The mandatory exit survey sample was $37 \%$ women and $51 \%$ U.S. citizens. The post-graduate survey was $36 \%$ women and $58 \%$ U.S. citizens. Hence, the post-graduate survey sample contained more U.S. citizens but a similar percentage of women, when compared to the mandatory exit survey sample. Sex disparities in the number of publications submitted favored men in both samples by a similar margin (gap of 2.3 submissions in the exit survey, versus 2.1 in the post-graduate survey), but the number of submissions was greater for both men and women in the exit survey than in the post-graduate survey (overall average of 5.5 versus 4.5 submissions). This difference is related to the larger percentage of international students in the mandatory exit sample. A supplemental analysis revealed that although the sex differences in publication rates (including those within fields) persisted in both U.S. and international samples, international students published an average of 1.6 more publications than did U.S. students (partially due to their over-representation in STEM fields).

7 Although the surveys were intended to be part of a longitudinal data collection effort in which doctoral students would be surveyed at four time points, only one survey was available for most students at the time of this study. Changes in university administration and priorities has made the future of these assessments uncertain. Hence, this analysis examines just one survey from each participating student.

${ }^{8}$ Given the questions' focus on publication, the survey likely undercounts other forms of scholarly work, such as that more common in the arts and humanities. Additionally, submission numbers will be higher in article-intensive fields than in book-intensive fields.

${ }^{9}$ In the initial (2013) version of this survey, the scale maximum for the publication variables was "10 or more." This caused an artificial ceiling, particularly on the "total submissions" variable, for which $20 \%$ of respondents chose "10 or more," (27\% of men and $7 \%$ of women). Hence, the scale maximum was increased to " 20 or more" in subsequent surveys. This initial low ceiling likely depressed the men's means, and therefore the actual sex differences in publications among survey respondents are likely a bit larger than those reported here. 
2. [If at least 1 submission reported]: Of the total number of submitted works you stated above, on how many were you listed as the first or solo author?

3. Of the total number of submitted works you stated above, how many have been accepted or published so far? [dropdown: None; $1 ; 2 ; 3 ; 4 ; 5 ; 6 ; 7 ; 8 ; 9 ; 10 ; 11 ; 12 ; 13 ; 14 ; 15 ; 16 ; 17$; $18 ; 19 ; 20$ or more]

Given that the data from these three variables are "counts" of publications, multilevel Poisson regression was used to examine predictors of the number of publications, with students nested within program groups. First, these multi-level models were used to examine the extent to which the number of works submitted, first-authored, and published varied by sex and program group (Tables A5-A6). Post hoc tests were used to determine whether sex differences for each of these three publication categories were significant within each program group. Given the multiple comparisons involved in this process, the Benjamini-Hochberg adjustment (for 15 comparisons) was used. ${ }^{10}$ The resulting significance levels are noted in Table 1 in the main text of the article.

Program satisfaction and support variables. Given the substantial sex disparities in publications found in this study, 12 additional survey items were examined that might provide potential reasons for the publication disparities. The first set of five items, shown in Table A2, were completed by the 1,285 students in the analytic sample, and $t$-tests were used to examine sex differences in responses, both overall and within each of the five program groups (with Bonferroni corrections ${ }^{11}$ ). Given sex differences in these variables, they were also included in an

${ }^{10}$ The Benjamini-Hochberg procedure was used due to the interdependence among the three publication variables. The more conservative Bonferroni correction assumes independence.

${ }^{11}$ Given the lack of a random sample of a larger population of graduate students, the $p$-values here are simply indicative of the strength of the evidence for disparities at this single institution, as opposed to indicating that the findings generalize to a larger population. There are many ways 
additional multilevel Poisson regression model in Table A5 to examine their relationship with the number of publications submitted. ${ }^{12}$

A second set of seven survey items appeared on the mandatory exit survey only, but were considered important to analyze further because of their potential relevance to sex differences in academic supports and obstacles that could relate to publication. Given the relatively small numbers of students completing these exit survey items (ranging from 546 to 734 students, depending on the item), all students from the main analytic sample who answered any of the seven survey items were included to the extent possible in initial comparisons by sex. Table A3 reports the means by sex within each program for all of the students who completed each item, as well as significant differences by sex as indicated by $t$-tests (again with Bonferroni corrections).

The variables were then also included in a supplemental multilevel Poisson analysis (Table A7). The sample for that analysis consisted of the 495 students from the original analytic sample ( $\mathrm{n}=1285)$ who had valid data for all seven of the supplementary survey items. Given the smaller sample sizes involved, any null results of this additional Poisson analysis should be

that multiple comparisons could be counted. The most stringent would likely assume 60 comparisons, given the examination of sex differences in five program groups for each of 12 supplemental survey variables ( 5 in set I and 7 in set II). However, if we used a Bonferroni adjustment with $n=60$, the study would reveal no significant patterns despite there clearly being gendered patterns in the data for this sample. Erring that far on the side of Type II errors would not serve the goal of illuminating potential factors that should be further examined in future studies. Instead, by using the Bonferroni correction to adjust for $n=5$ program groups within each of the 12 explanatory variables, we hope to balance the need for caution, while not being so cautious that fields with smaller sample sizes (but substantial effect sizes) are assumed to have no sex differences. This is particularly important, given this study's intention to explore the patterns in one university and flag those that are potentially problematic and could generalize elsewhere. For this reason, we also note in Tables A2 and A3 when comparisons lost their significance due to the Bonferroni correction.

12 The number of submissions is arguably the most important of the three publication variables to examine because the other two variables (first authorship and being published) are a subset of the number of submissions reported, and they depend on field-varying conventions regarding authorship order and review process time. 
interpreted cautiously.

Primary career goal. Finally, the subsample of students who completed the postgraduation survey were asked about their "primary career goal" (Table A4). Differences in proportions were examined using Z-tests. This question was answered by only 523 of the 1285 students in the main analytic sample. Given that there were eight categories for this variable (e.g., Research Faculty, Teaching Faculty, Government, Private Sector, etc.) the limited sample could not support more detailed analyses by program and sex. 


\section{Appendix Tables and Figures}

Table A1

Number of Men and Women by Program and Program Group

\begin{tabular}{|c|c|c|c|c|}
\hline \multirow[t]{2}{*}{ Assessment Group } & & \multicolumn{2}{|c|}{ Sex } & \multirow[t]{2}{*}{ Total } \\
\hline & & Men & Women & \\
\hline Social Sciences and & Agricultural \& Applied Economics & 9 & 1 & 10 \\
\hline \multirow[t]{21}{*}{ Applied Health } & Anthropology & 8 & 6 & 14 \\
\hline & Audiology (AUD) & 1 & 2 & 3 \\
\hline & Communication (LAS) & 4 & 7 & 11 \\
\hline & Communications \& Media (Media) & 9 & 7 & 16 \\
\hline & Community Health & 6 & 7 & 13 \\
\hline & Economics & 13 & 4 & 17 \\
\hline & Food Science \& Human Nutrition & 7 & 5 & 12 \\
\hline & Geography & 5 & 1 & 6 \\
\hline & Human \& Community Development & 1 & 5 & 6 \\
\hline & Informatics & 2 & 0 & 2 \\
\hline & Kinesiology & 6 & 5 & 11 \\
\hline & Nutritional Science & 4 & 13 & 17 \\
\hline & Political Science & 7 & 1 & 8 \\
\hline & Psychology & 16 & 26 & 42 \\
\hline & Recreation, Sport \& Tourism & 2 & 3 & 5 \\
\hline & Sociology & 5 & 1 & 6 \\
\hline & Speech \& Hearing Science & 0 & 3 & 3 \\
\hline & Veterinary Clinical Medicine & 1 & 0 & 1 \\
\hline & VMS - Comparative Biosciences & 2 & 2 & 4 \\
\hline & VMS - Pathobiology & 1 & 0 & 1 \\
\hline & Total & 109 & 99 & 208 \\
\hline Natural and & Agricultural \& Biological Engineering & 6 & 3 & 9 \\
\hline \multirow[t]{17}{*}{ Biological Sciences } & Animal Sciences & 16 & 9 & 25 \\
\hline & Astronomy & 3 & 6 & 9 \\
\hline & Atmospheric Sciences & 5 & 2 & 7 \\
\hline & Biochemistry & 13 & 13 & 26 \\
\hline & Biology: Ecology, Ethology and Evolution & 0 & 6 & 6 \\
\hline & Biophysics \& Computational Biology & 12 & 3 & 15 \\
\hline & Cell and Developmental Biology & 5 & 6 & 11 \\
\hline & Crop Sciences & 14 & 3 & 17 \\
\hline & Ecology, Evolution, Conservation Biology & 2 & 2 & 4 \\
\hline & Entomology & 2 & 4 & 6 \\
\hline & Geology & 3 & 1 & 4 \\
\hline & Microbiology & 5 & 8 & 13 \\
\hline & Molecular \& Integrative Physiology & 3 & 6 & 9 \\
\hline & Natural Resources \& Environmental Science & 9 & 2 & 11 \\
\hline & Neuroscience & 3 & 9 & 12 \\
\hline & Plant Biology & 5 & 4 & 9 \\
\hline & Total & 106 & 87 & 193 \\
\hline Engineering and & Aerospace Engineering & 12 & 0 & 12 \\
\hline \multirow[t]{7}{*}{ Physical Sciences } & Bioengineering & 9 & 5 & 14 \\
\hline & Chemical Engineering & 14 & 8 & 22 \\
\hline & Chemical Physics & 2 & 0 & 2 \\
\hline & Chemistry & 48 & 28 & 76 \\
\hline & Civil Engineering & 40 & 8 & 48 \\
\hline & Computer Science & 53 & 8 & 61 \\
\hline & Electrical \& Computer Engineering & 104 & 12 & 116 \\
\hline
\end{tabular}




\begin{tabular}{|c|c|c|c|c|}
\hline & Environmental Engineering in Civil Engineering & 7 & 4 & 11 \\
\hline & Industrial Engineering & 10 & 4 & 14 \\
\hline & Materials Science \& Engineering & 30 & 13 & 43 \\
\hline & Mathematics & 25 & 5 & 30 \\
\hline & Mechanical Engineering & 43 & 3 & 46 \\
\hline & Nuclear, Plasma \& Radiological Engineering & 6 & 1 & 7 \\
\hline & Physics & 48 & 9 & 57 \\
\hline & Statistics & 1 & 1 & 2 \\
\hline & Systems \& Entrepreneurial Engineering & 2 & 1 & 3 \\
\hline & Theoretical \& Applied Mechanics & 15 & 2 & 17 \\
\hline & Total & 469 & 112 & 581 \\
\hline \multirow{17}{*}{$\begin{array}{l}\text { Education and } \\
\text { Professional } \\
\text { Programs }\end{array}$} & Accountancy & 5 & 4 & 9 \\
\hline & Architecture & 3 & 5 & 8 \\
\hline & Business Administration & 7 & 3 & 10 \\
\hline & Curriculum and Instruction (EdD) & 0 & 1 & 1 \\
\hline & Curriculum and Instruction (PhD) & 0 & 11 & 11 \\
\hline & Educ Policy, Organization \& Leadership (PhD) & 28 & 29 & 57 \\
\hline & Educational Psychology & 5 & 14 & 19 \\
\hline & Finance & 4 & 2 & 6 \\
\hline & Human Resource Education (PhD) & 3 & 2 & 5 \\
\hline & Human Resources \& Industrial Relations & 1 & 1 & 2 \\
\hline & Landscape Architecture & 1 & 1 & 2 \\
\hline & Law (JSD) & 1 & 2 & 3 \\
\hline & Library \& Information Science & 5 & 10 & 15 \\
\hline & Regional Planning & 3 & 2 & 5 \\
\hline & Social Work & 0 & 5 & 5 \\
\hline & Special Education $(\mathrm{PhD})$ & 0 & 8 & 8 \\
\hline & Total & 66 & 100 & 166 \\
\hline \multirow{18}{*}{$\begin{array}{l}\text { Humanities and } \\
\text { Creative Arts }\end{array}$} & Art Education & 3 & 1 & 4 \\
\hline & Art History & 0 & 5 & 5 \\
\hline & Classical Philology & 2 & 1 & 3 \\
\hline & Comparative Literature & 1 & 4 & 5 \\
\hline & East Asian Languages \& Cultures & 0 & 3 & 3 \\
\hline & English & 8 & 14 & 22 \\
\hline & French & 3 & 2 & 5 \\
\hline & German & 0 & 4 & 4 \\
\hline & History & 13 & 14 & 27 \\
\hline & Linguistics & 7 & 4 & 11 \\
\hline & Music (AMusD) & 10 & 7 & 17 \\
\hline & Music Education (PhD) & 3 & 0 & 3 \\
\hline & Musicology & 3 & 4 & 7 \\
\hline & Philosophy & 4 & 1 & 5 \\
\hline & Slavic Languages \& Literature & 0 & 2 & 2 \\
\hline & Spanish & 2 & 7 & 9 \\
\hline & Theatre & 3 & 2 & 5 \\
\hline & Total & 62 & 75 & 137 \\
\hline \multicolumn{2}{|c|}{ Total Across All Programs } & 812 & 473 & 1,285 \\
\hline
\end{tabular}



Table A2

Program Satisfaction and Employment by $\operatorname{Sex}(n=1,285)$

\begin{tabular}{|c|c|c|c|c|c|c|c|c|}
\hline \multirow[t]{2}{*}{ Survey Item } & \multirow[t]{2}{*}{ Program Group } & \multicolumn{3}{|c|}{$\begin{array}{c}\text { Men } \\
(n=812)\end{array}$} & \multicolumn{3}{|c|}{$\begin{array}{l}\text { Women } \\
(n=473)\end{array}$} & \multirow{2}{*}{$\begin{array}{l}\text { Effect Size } \\
(\text { Cohen's } d)\end{array}$} \\
\hline & & Mean & SE & $n$ & Mean & SE & $n$ & \\
\hline \multirow{6}{*}{$\begin{array}{l}\text { How satisfied are you with } \\
\text { the quality of relationship } \\
\text { with your primary faculty }^{\text {advisor? }}{ }^{\text {a }}\end{array}$} & Social Sciences and Applied Health & 4.41 & 0.09 & 109 & 3.81 & 0.13 & 99 & $0.56 * * *$ \\
\hline & Natural and Biological Sciences & 4.07 & 0.12 & 106 & 3.85 & 0.12 & 87 & 0.18 \\
\hline & Engineering and Physical Sciences & 4.19 & 0.05 & 469 & 3.95 & 0.10 & 112 & $0.24^{+}$ \\
\hline & Education and Professional Programs & 4.38 & 0.09 & 66 & 4.21 & 0.10 & 100 & 0.19 \\
\hline & Humanities and Creative Arts & 4.06 & 0.14 & 62 & 4.29 & 0.12 & 75 & -0.21 \\
\hline & Total & 4.21 & 0.04 & 812 & 4.01 & 0.05 & 473 & $0.19^{* *}$ \\
\hline \multirow{6}{*}{$\begin{array}{l}\text { How collegial (collaborative, } \\
\text { friendly) was the } \\
\text { environment in your doctoral } \\
\text { program? }\end{array}$} & Social Sciences and Applied Health & 3.89 & 0.10 & 109 & 3.65 & 0.13 & 99 & 0.21 \\
\hline & Natural and Biological Sciences & 3.85 & 0.07 & 106 & 3.92 & 0.10 & 87 & -0.07 \\
\hline & Engineering and Physical Sciences & 3.94 & 0.04 & 469 & 3.99 & 0.09 & 112 & -0.06 \\
\hline & Education and Professional Programs & 3.94 & 0.11 & 66 & 3.47 & 0.11 & 100 & $0.44 *$ \\
\hline & Humanities and Creative Arts & 3.52 & 0.15 & 62 & 3.67 & 0.12 & 75 & -0.14 \\
\hline & Total & 3.88 & 0.03 & 812 & 3.74 & 0.05 & 473 & $0.14^{*}$ \\
\hline \multirow{6}{*}{$\begin{array}{l}\text { How well do you think your } \\
\text { doctoral program prepared } \\
\text { you to begin a career in your } \\
\text { discipline? }\end{array}$} & Social Sciences and Applied Health & 4.00 & 0.09 & 109 & 3.73 & 0.11 & 99 & $0.27^{+}$ \\
\hline & Natural and Biological Sciences & 3.97 & 0.09 & 106 & 3.60 & 0.10 & 87 & $0.42 *$ \\
\hline & Engineering and Physical Sciences & 4.04 & 0.04 & 469 & 3.87 & 0.07 & 112 & $0.22^{+}$ \\
\hline & Education and Professional Programs & 3.79 & 0.12 & 66 & 3.66 & 0.11 & 100 & 0.13 \\
\hline & Humanities and Creative Arts & 3.71 & 0.12 & 62 & 3.73 & 0.11 & 75 & -0.02 \\
\hline & Total & 3.98 & 0.03 & 812 & 3.72 & 0.04 & 473 & $0.28 * * *$ \\
\hline \multirow{6}{*}{$\begin{array}{l}\text { Were you employed as a } \\
\text { TA? }{ }^{\text {d }}\end{array}$} & Social Sciences and Applied Health & 0.85 & 0.03 & 109 & 0.86 & 0.04 & 99 & -0.02 \\
\hline & Natural and Biological Sciences & 0.72 & 0.04 & 106 & 0.85 & 0.04 & 87 & $-0.32^{+}$ \\
\hline & Engineering and Physical Sciences & 0.75 & 0.02 & 469 & 0.78 & 0.04 & 112 & -0.07 \\
\hline & Education and Professional Programs & 0.61 & 0.06 & 66 & 0.70 & 0.05 & 100 & -0.20 \\
\hline & Humanities and Creative Arts & 0.85 & 0.05 & 62 & 0.95 & 0.03 & 75 & -0.31 \\
\hline & Total & 0.75 & 0.02 & 812 & 0.82 & 0.02 & 473 & $-0.16 * *$ \\
\hline \multirow{6}{*}{$\begin{array}{l}\text { Were you employed as an } \\
\text { RA? }{ }^{\text {d }}\end{array}$} & Social Sciences and Applied Health & 0.70 & 0.04 & 109 & 0.83 & 0.04 & 99 & $-0.31^{+}$ \\
\hline & Natural and Biological Sciences & 0.94 & 0.02 & 106 & 0.87 & 0.04 & 87 & 0.25 \\
\hline & Engineering and Physical Sciences & 0.95 & 0.01 & 469 & 0.96 & 0.02 & 112 & -0.02 \\
\hline & Education and Professional Programs & 0.56 & 0.06 & 66 & 0.71 & 0.05 & 100 & $-0.32^{+}$ \\
\hline & Humanities and Creative Arts & 0.45 & 0.06 & 62 & 0.56 & 0.06 & 75 & -0.22 \\
\hline & Total & 0.85 & 0.01 & 812 & 0.80 & 0.02 & 473 & $0.12 *$ \\
\hline
\end{tabular}

$* p<.05, * * p<.01, * * * p<.001$

+ Indicates a comparison that was significant before the Bonferroni correction.

Note. Significance levels for total sample refer to $t$-test results comparing men's and women's means, while significance levels by program group refer to $t$-test results comparing men's and women's means, after applying a Bonferroni correction for 5 comparisons to each variable. 
${ }^{\text {a }}$ Scale for this item was: $1=$ not at all satisfied, $2=$ slightly satisfied, $3=$ moderately satisfied, $4=$ very satisfied, and $5=$ extremely satisfied. ${ }^{\mathrm{b}}$ Scale for this item was: $1=$ not at all collegial, $2=$ slightly collegial, $3=$ moderately collegial, $4=$ very collegial, and $5=$ extremely collegial.

${ }^{c}$ Scale for this item was: $1=$ not well at all, $2=$ not very well, $3=$ moderately well, $4=$ very well, and $5=$ extremely well.

${ }^{\mathrm{d}}$ Scale for this item was $1=$ yes, $0=$ no. 
Table A3

Supplemental Analysis: Supports and Barriers to Progress by Sex in Subsample

\begin{tabular}{|c|c|c|c|c|c|c|c|c|}
\hline \multirow{2}{*}{ Survey Item } & \multirow{2}{*}{ Program Group } & \multicolumn{3}{|c|}{ Men } & \multicolumn{3}{|c|}{ Women } & \multirow{2}{*}{$\begin{array}{l}\text { Effect Size } \\
\text { (Cohen's } d\end{array}$} \\
\hline & & Mean & SE & $n$ & Mean & SE & $n$ & \\
\hline \multirow{6}{*}{$\begin{array}{l}\text { To what extent did } \\
\text { program faculty } \\
\text { encourage and support } \\
\text { your publication of } \\
\text { scholarly work? }^{\text {a }}\end{array}$} & Social Sciences and Applied Health & 3.97 & 0.15 & 59 & 3.68 & 0.18 & 47 & 0.24 \\
\hline & Natural and Biological Sciences & 4.19 & 0.12 & 63 & 3.82 & 0.14 & 50 & $0.38^{+}$ \\
\hline & Engineering and Physical Sciences & 4.20 & 0.05 & 264 & 3.97 & 0.13 & 75 & 0.24 \\
\hline & Education and Professional Programs & 4.00 & 0.16 & 37 & 3.51 & 0.16 & 59 & $0.43^{+}$ \\
\hline & Humanities and Creative Arts & 3.55 & 0.18 & 38 & 3.40 & 0.20 & 42 & 0.12 \\
\hline & Total & 4.10 & 0.05 & 461 & 3.71 & 0.07 & 273 & $0.37 * * *$ \\
\hline \multirow{6}{*}{$\begin{array}{l}\text { To what extent did your } \\
\text { advisor support you in } \\
\text { the career path of your } \\
\text { choosing? }\end{array}$} & Social Sciences and Applied Health & 4.28 & 0.14 & 50 & 3.94 & 0.18 & 52 & 0.29 \\
\hline & Natural and Biological Sciences & 3.88 & 0.19 & 42 & 4.19 & 0.17 & 37 & -0.27 \\
\hline & Engineering and Physical Sciences & 3.89 & 0.08 & 202 & 3.49 & 0.22 & 37 & 0.33 \\
\hline & Education and Professional Programs & 3.97 & 0.21 & 29 & 4.05 & 0.19 & 40 & -0.07 \\
\hline & Humanities and Creative Arts & 4.13 & 0.22 & 24 & 4.45 & 0.14 & 33 & -0.36 \\
\hline & Total & 3.97 & 0.06 & 347 & 4.01 & 0.08 & 199 & -0.04 \\
\hline \multirow{6}{*}{$\begin{array}{l}\text { How much of an } \\
\text { obstacle to academic } \\
\text { progress: Teaching } \\
\text { responsibilities }{ }^{b}\end{array}$} & Social Sciences and Applied Health & 1.74 & 0.09 & 53 & 1.93 & 0.11 & 44 & -0.28 \\
\hline & Natural and Biological Sciences & 1.61 & 0.09 & 54 & 1.80 & 0.10 & 45 & -0.27 \\
\hline & Engineering and Physical Sciences & 1.44 & 0.04 & 223 & 1.45 & 0.08 & 65 & -0.01 \\
\hline & Education and Professional Programs & 1.63 & 0.09 & 27 & 1.55 & 0.10 & 49 & 0.13 \\
\hline & Humanities and Creative Arts & 1.67 & 0.11 & 33 & 2.00 & 0.11 & 40 & $-0.49^{+}$ \\
\hline & Total & 1.54 & 0.03 & 390 & 1.71 & 0.05 & 243 & $-0.26 * *$ \\
\hline \multirow{6}{*}{$\begin{array}{l}\text { How much of an } \\
\text { obstacle to academic } \\
\text { progress: Family } \\
\text { obligations }^{b}\end{array}$} & Social Sciences and Applied Health & 1.62 & 0.10 & 50 & 1.51 & 0.11 & 43 & 0.15 \\
\hline & Natural and Biological Sciences & 1.50 & 0.09 & 62 & 1.44 & 0.09 & 45 & 0.09 \\
\hline & Engineering and Physical Sciences & 1.40 & 0.04 & 239 & 1.51 & 0.08 & 70 & -0.18 \\
\hline & Education and Professional Programs & 1.85 & 0.11 & 34 & 1.91 & 0.11 & 53 & -0.07 \\
\hline & Humanities and Creative Arts & 1.58 & 0.11 & 33 & 1.64 & 0.12 & 36 & -0.09 \\
\hline & Total & 1.49 & 0.03 & 418 & 1.60 & 0.05 & 247 & $-0.16^{*}$ \\
\hline \multirow{5}{*}{$\begin{array}{l}\text { How much of an } \\
\text { obstacle to academic } \\
\text { progress: Program } \\
\text { climate regarding racial, } \\
\text { ethnic, gender, or sexual }\end{array}$} & Social Sciences and Applied Health & 1.17 & 0.06 & 48 & 1.49 & 0.12 & 41 & $-0.54^{+}$ \\
\hline & Natural and Biological Sciences & 1.08 & 0.04 & 59 & 1.22 & 0.07 & 45 & -0.34 \\
\hline & Engineering and Physical Sciences & 1.04 & 0.01 & 229 & 1.15 & 0.05 & 72 & $-0.38 *$ \\
\hline & Education and Professional Programs & 1.10 & 0.08 & 29 & 1.27 & 0.08 & 49 & -0.31 \\
\hline & Humanities and Creative Arts & 1.13 & 0.08 & 31 & 1.36 & 0.11 & 39 & -0.40 \\
\hline
\end{tabular}




\begin{tabular}{|c|c|c|c|c|c|c|c|c|}
\hline minorities ${ }^{b}$ & Total & 1.08 & 0.02 & 396 & 1.28 & 0.04 & 246 & $-0.47 * * *$ \\
\hline \multirow{6}{*}{$\begin{array}{l}\text { How much of an } \\
\text { obstacle to academic } \\
\text { progress: Work or } \\
\text { financial commitments }\end{array}$} & Social Sciences and Applied Health & 1.68 & 0.10 & 50 & 1.90 & 0.11 & 41 & -0.31 \\
\hline & Natural and Biological Sciences & 1.43 & 0.09 & 60 & 1.39 & 0.10 & 41 & 0.06 \\
\hline & Engineering and Physical Sciences & 1.36 & 0.04 & 232 & 1.24 & 0.06 & 62 & 0.21 \\
\hline & Education and Professional Programs & 1.94 & 0.14 & 34 & 2.11 & 0.11 & 56 & -0.20 \\
\hline & Humanities and Creative Arts & 1.79 & 0.10 & 33 & 2.10 & 0.11 & 39 & $-0.47^{+}$ \\
\hline & Total & 1.49 & 0.03 & 409 & 1.72 & 0.05 & 239 & $-0.32 * * *$ \\
\hline \multirow{6}{*}{$\begin{array}{l}\text { How much of an } \\
\text { obstacle to academic } \\
\text { progress: Availability of } \\
\text { faculty }{ }^{b}\end{array}$} & Social Sciences and Applied Health & 1.38 & 0.08 & 52 & 1.67 & 0.12 & 45 & -0.40 \\
\hline & Natural and Biological Sciences & 1.41 & 0.09 & 63 & 1.39 & 0.09 & 49 & 0.04 \\
\hline & Engineering and Physical Sciences & 1.30 & 0.03 & 254 & 1.41 & 0.07 & 75 & -0.21 \\
\hline & Education and Professional Programs & 1.64 & 0.11 & 36 & 1.59 & 0.09 & 56 & 0.07 \\
\hline & Humanities and Creative Arts & 1.49 & 0.12 & 37 & 1.68 & 0.12 & 41 & -0.26 \\
\hline & Total & 1.37 & 0.03 & 442 & 1.53 & 0.04 & 266 & $-0.26 * *$ \\
\hline
\end{tabular}

$* p<.05, * * p<.01, * * * p<.001$

+ Used to indicate a comparison whose significance was eliminated due to the Bonferroni correction.

Note 1. Significance levels for total sample refer to $t$-test results comparing men's and women's means, while significance levels by program group refer to $t$-test results after applying a Bonferroni correction for the 5 program group comparisons to each variable.

Note 2. As discussed above, the seven items in this table were included on the exit survey only, and therefore sample sizes are smaller for these items than for items in Table A2. Additionally, sample sizes for these items vary due to missing data. Given the relatively small samples within each program, samples are maximized here instead of restricting the sample to only those students who answered every question. Hence, $n$ 's for these items vary, but all students included here are part of the main sample of 1,285 students.

a Scale for this item was: $1=$ not at all, $2=$ a little, $3=$ a moderate amount, $4=$ a lot, and $5=$ a great deal.

${ }^{\mathrm{b}}$ Scale for this item was: $1=$ not an obstacle, $2=$ a minor obstacle, and $3=$ a major obstacle. 
Table A4

Primary Career Goal by Sex (subsample $n=523)^{\mathrm{a}}$

\begin{tabular}{l|cc|cc}
\hline \multirow{2}{*}{ Primary Career Goal } & \multicolumn{2}{|c|}{ Men } & \multicolumn{2}{c}{ Women } \\
\cline { 2 - 5 } & $n$ & $\%$ & $n$ & $\%$ \\
\hline Research-intensive faculty position & 112 & 33 & 46 & $25^{*}$ \\
Teaching-intensive faculty position & 23 & 7 & 22 & 12 \\
Balanced research/teaching faculty position & 60 & 18 & 51 & $27^{*}$ \\
Non-teaching research position & 22 & 7 & 16 & 9 \\
Higher education administration & 6 & 2 & 10 & 5 \\
Government or non-profit & 16 & 5 & 10 & 5 \\
(including preschool or K-12 education) & 82 & 24 & 20 & $11^{*}$ \\
Private sector (for-profit organizations) & 15 & 5 & 12 & 6 \\
Other/Unsure & 336 & 100 & 187 & 100 \\
\hline Total &
\end{tabular}

${ }^{a}$ Item asked on the post-graduation survey only. This sample is a subset of the main analytic sample of 1285 students, but is distinct from the exit survey sample featured in Table A3 above. $* \mathrm{p}<.05$ according to Z-test comparing column proportions for men and women, with Bonferroni correction for 8 comparisons applied. Overall Pearson chi-Square $=29.6(\mathrm{p}<.001)$. 
Table A5

Poisson Regression Results for Total Number of Publications Submitted $(n=1,285)$

\begin{tabular}{|c|c|c|c|c|c|c|}
\hline & \multicolumn{2}{|c|}{ Model 1} & \multicolumn{2}{|c|}{ Model 2} & \multicolumn{2}{|c|}{ Model 3} \\
\hline & $\begin{array}{c}\beta \\
\text { (S.E.) }\end{array}$ & $\begin{array}{l}\text { Rate Ratio } \\
\exp (\beta)\end{array}$ & $\begin{array}{c}\beta \\
\text { (S.E.) }\end{array}$ & $\begin{array}{l}\text { Rate Ratio } \\
\exp (\beta)\end{array}$ & $\begin{array}{c}\beta \\
\text { (S.E.) }\end{array}$ & $\begin{array}{l}\text { Rate Ratio } \\
\exp (\beta)\end{array}$ \\
\hline Male & $\begin{array}{l}0.26^{* * *} \\
(0.03)\end{array}$ & 1.29 & $\begin{array}{l}0.55^{* * *} \\
(0.12)\end{array}$ & 1.73 & $\begin{array}{l}0.60^{* * *} \\
(0.12)\end{array}$ & 1.82 \\
\hline SocAppH & $\begin{array}{l}0.56^{* * *} \\
(0.07)\end{array}$ & 1.75 & $\begin{array}{l}0.76^{* * *} \\
(0.10)\end{array}$ & 2.14 & $\begin{array}{l}0.65^{* * *} \\
(0.10)\end{array}$ & 1.91 \\
\hline NatBio & $\begin{array}{l}0.68^{* * *} \\
(0.07)\end{array}$ & 1.97 & $\begin{array}{l}0.79^{* * *} \\
(0.10)\end{array}$ & 2.20 & $\begin{array}{l}0.67^{* * *} \\
(0.11)\end{array}$ & 1.95 \\
\hline EnginPhys & $\begin{array}{l}1.01^{* * *} \\
(0.06)\end{array}$ & 2.75 & $\begin{array}{l}1.16^{* * *} \\
(0.10)\end{array}$ & 3.18 & $\begin{array}{l}0.96^{* * *} \\
(0.10)\end{array}$ & 2.60 \\
\hline EdProf & $\begin{array}{l}0.27^{* * *} \\
(0.07)\end{array}$ & 1.31 & $\begin{array}{l}0.57^{* * *} \\
(0.11)\end{array}$ & 1.76 & $\begin{array}{l}0.47^{* * *} \\
(0.11)\end{array}$ & 1.60 \\
\hline Male*SocAppH & & & $\begin{array}{l}-0.36^{* *} \\
(0.13)\end{array}$ & 0.70 & $\begin{array}{l}-0.41^{* *} \\
(0.13)\end{array}$ & 0.66 \\
\hline Male*NatBio & & & $\begin{array}{l}-0.21 \\
(0.13)\end{array}$ & 0.81 & $\begin{array}{l}-0.35^{* *} \\
(0.13)\end{array}$ & 0.70 \\
\hline Male*EnginPhys & & & $\begin{array}{l}-0.28^{*} \\
(0.12)\end{array}$ & 0.76 & $\begin{array}{l}-0.35^{* *} \\
(0.12)\end{array}$ & 0.70 \\
\hline Male*EdProf & & & $\begin{array}{l}-0.62^{* * *} \\
(0.15)\end{array}$ & 0.54 & $\begin{array}{l}-0.61^{* * *} \\
(0.15)\end{array}$ & 0.54 \\
\hline Satisf_Advisor & & & & & $\begin{array}{l}0.06^{* * *} \\
(0.01)\end{array}$ & 1.06 \\
\hline Career_Prep & & & & & $\begin{array}{l}0.08^{* * *} \\
(0.02)\end{array}$ & 1.08 \\
\hline TA & & & & & $\begin{array}{l}-0.13^{* * *} \\
(0.03)\end{array}$ & 0.87 \\
\hline RA & & & & & $\begin{array}{l}0.53^{* * *} \\
(0.05)\end{array}$ & 1.70 \\
\hline Intercept & $\begin{array}{l}0.71^{* * *} \\
(0.06)\end{array}$ & 2.03 & $\begin{array}{l}0.54 * * * \\
(0.09)\end{array}$ & 1.72 & $\begin{array}{l}0.34^{* * *} \\
(0.10)\end{array}$ & 1.41 \\
\hline $\begin{array}{l}\text { Omnibus Test for } \\
\text { Interaction } \\
\text { Coefficients a }\end{array}$ & & & $\chi^{2}(4)=$ & $.29 * * *$ & $\chi^{2}(4)=$ & $17.76^{* *}$ \\
\hline
\end{tabular}

${ }^{a} \mathrm{~A}$ chi-squared test was used to determine if any of the interaction coefficients differed significantly from zero $\left(\mathrm{H}_{0}\right.$ : Male $* \mathrm{SocAppH}=$ Male*NatBio $=$ Male*EnginPhys $=$ Male $*$ EdProf $=0)$.

Note 1. Likert scale items (Satisf_Advisor and Career_Prep) were grand mean centered for ease of interpretation. Model 3 was run with and without the survey item pertaining to program collegiality, but the variable was ultimately omitted from the final model for parsimony. When included, collegiality was the only one of the five survey variables that was not a predictor of publications, and it did not differ by sex for the four program groups in which there were sex differences in publications (see Table A2). 
Note 2. Interpreting Poisson regression output, particularly when interactions are involved, requires some care. As is typical, $p$-values marked here indicate whether the coefficients are significantly different than 0 . To interpret their meaning, the coefficients can be converted to rate ratios with the exponential function $\left(\mathrm{e}^{x}\right)$. Hence, the male coefficient of 0.26 in Model 1 means that, overall, men submitted $\mathrm{e}^{0.26}=1.29$ times as many publications as women. Humanities and Creative Arts is the omitted program group, and so the positive coefficients for the other four program groups in Model 1 indicate that their mean number of publications is higher than that of Humanities and Creative Arts. When sex by program interactions are included, as they are in Model 2, then the male rate ratio must be multiplied by the interaction for a program group in order to get the rate by which men's submissions differed from women's submissions in that group. For example, within Social Science and Applied Health, Model 2 results indicate that men publish 1.73 x $0.70=1.21$ times as many articles as their female counterparts, which corresponds with the means provided in Table 1, given that 3.68 (women's mean) x $1.21=4.45$ (men's mean). So while actual differences in men's and women's publication rates are shown in Table 1, these regression analyses here allow us to test significant differences, as well as to examine the role of the five survey variables (from Table A2) in predicting publication rates. Post-hoc tests were run to determine whether the Model 2 sex differences for each program group were statistically significant, and the same tests were conducted for the number of publications first-authored and published in Table A6 below. The significance levels from these regression analyses were corrected using the Benjamini-Hochberg procedure (for $n=15$ comparisons) and are reported in Table 1.

Note 3. The addition of the survey variables in Model 3 allow us to examine the change in the rate ratios before and after the addition of those variables. After adding the survey variables, we see only small changes in the rate by which men's submissions differed from women's submissions within program groups. For example, the sex disparity in rates for natural/biological sciences decreased from 1.40 (obtained by multiplying $1.73 \mathrm{x} .81$ ) to 1.27 (obtained by multiplying 1.82 to .7). Decreases in the engineering/physical sciences and social sciences/applied health were even smaller, while the rates for humanities/arts and for education/professional programs increased slightly. Hence, these variables do relatively little to explain the gender disparities in publication rates. The same is true in Table A7 below. 
Table A6

Poisson Regression Results for Number of Publications Submitted as First Author and Number of Publications Accepted or Published $(n=1,285)$

\begin{tabular}{|c|c|c|c|c|}
\hline & \multicolumn{2}{|c|}{$\begin{array}{c}\text { Total Number of } \\
\text { Publications Submitted } \\
\text { as First Author }\end{array}$} & \multicolumn{2}{|c|}{$\begin{array}{c}\text { Total Number of } \\
\text { Publications Accepted or } \\
\text { Published }\end{array}$} \\
\hline & $\begin{array}{c}\beta \\
\text { (S.E.) }\end{array}$ & $\begin{array}{c}\text { Rate Ratio } \\
\exp (\beta)\end{array}$ & $\begin{array}{c}\beta \\
\text { (S.E.) }\end{array}$ & $\begin{array}{l}\text { Rate Ratio } \\
\exp (\beta)\end{array}$ \\
\hline Male & $\begin{array}{l}0.44 * * * \\
(0.12)\end{array}$ & 1.55 & $\begin{array}{l}0.51 * * * \\
(0.13)\end{array}$ & 1.67 \\
\hline SocAppH & $\begin{array}{c}0.21 \\
(0.12)\end{array}$ & 1.24 & $\begin{array}{l}0.77 * * * \\
(0.12)\end{array}$ & 2.17 \\
\hline NatBio & $\begin{array}{l}0.48^{* * * *} \\
(0.12)\end{array}$ & 1.61 & $\begin{array}{l}0.80 * * * \\
(0.12)\end{array}$ & 2.21 \\
\hline EnginPhys & $\begin{array}{l}0.76^{* * *} \\
(0.11)\end{array}$ & 2.13 & $\begin{array}{l}1.19 * * * \\
(0.11)\end{array}$ & 3.28 \\
\hline EdProf & $\begin{array}{c}0.09 \\
(0.12) \\
\end{array}$ & 1.09 & $\begin{array}{l}0.53 * * * \\
(0.12)\end{array}$ & 1.69 \\
\hline Male*SocAppH & $\begin{array}{l}-0.07 \\
(0.16)\end{array}$ & 0.93 & $\begin{array}{l}-0.36^{*} \\
(0.15)\end{array}$ & 0.70 \\
\hline Male*NatBio & $\begin{array}{l}-0.17 \\
(0.15)\end{array}$ & 0.84 & $\begin{array}{l}-0.16 \\
(0.15)\end{array}$ & 0.85 \\
\hline Male*EnginPhys & $\begin{array}{l}-0.11 \\
(0.14)\end{array}$ & 0.89 & $\begin{array}{l}-0.19 \\
(0.14)\end{array}$ & 0.83 \\
\hline Male*EdProf & $\begin{array}{l}-0.42^{*} \\
(0.17)\end{array}$ & 0.66 & $\begin{array}{c}-0.64 * * * \\
(0.17)\end{array}$ & 0.53 \\
\hline Intercept & $\begin{array}{l}0.43 * * * \\
(0.09)\end{array}$ & 1.53 & $\begin{array}{l}0.31 * * \\
(0.10)\end{array}$ & 1.36 \\
\hline $\begin{array}{l}\text { Omnibus Test for } \\
\text { Interaction } \\
\text { Coefficients }^{\text {a }}\end{array}$ & $\chi^{2}(4)$ & 7.34 & $\chi^{2}(4)=$ & $.27 * * *$ \\
\hline
\end{tabular}

$* p<.05, * * p<.01, * * * p<.001$

${ }^{a}$ A chi-squared test was used to determine if any of the interaction coefficients differed significantly from zero $\left(\mathrm{H}_{0}\right.$ : Male*SocAppH $=$ Male*NatBio $=$ Male*EnginPhys $=$ Male*EdProf $=0$ ). However, readers are cautioned that the true male-female difference within programs is not simply captured by these interactions (see note following Table A5 above). Sex differences within each program can be found in Table 1 in the main text, including the results of the posthoc tests of significance.

Note. See Table A4 note for details on how to interpret these multilevel Poisson regression results. 
Running Head: SEX DIFFERENCES IN DOCTORAL PUBLICATIONS

Table A7

Supplemental Poisson Regression Analysis for Total Number of Publications Submitted (subsample $n=495)$

\begin{tabular}{|c|c|c|c|c|c|c|c|c|}
\hline & \multicolumn{2}{|c|}{ Model 1} & \multicolumn{2}{|c|}{ Model 2} & \multicolumn{2}{|c|}{ Model 3} & \multicolumn{2}{|c|}{ Model 4} \\
\hline & $\begin{array}{c}\beta \\
(\mathrm{S} . \mathrm{E} .)\end{array}$ & $\begin{array}{c}\text { Rate } \\
\text { Ratio } \\
\exp (\beta)\end{array}$ & $\begin{array}{c}\beta \\
(\text { S.E.) }\end{array}$ & $\begin{array}{c}\text { Rate } \\
\text { Ratio } \\
\exp (\beta)\end{array}$ & $\begin{array}{c}\beta \\
\text { (S.E.) }\end{array}$ & $\begin{array}{c}\text { Rate } \\
\text { Ratio } \\
\exp (\beta)\end{array}$ & $\begin{array}{c}\beta \\
(\mathrm{S} . \mathrm{E} .)\end{array}$ & $\begin{array}{c}\text { Rate } \\
\text { Ratio } \\
\exp (\beta) \\
\end{array}$ \\
\hline Male & $\begin{array}{l}0.29 * * * \\
(0.05)\end{array}$ & 1.34 & $\begin{array}{l}-0.06 \\
(0.17)\end{array}$ & 0.94 & $\begin{array}{l}-0.05 \\
(0.17)\end{array}$ & 0.95 & $\begin{array}{l}-0.13 \\
(0.17)\end{array}$ & 0.88 \\
\hline SocAppH & $\begin{array}{l}0.53 * * * \\
(0.10)\end{array}$ & 1.70 & $\begin{array}{l}0.32 * \\
(0.15)\end{array}$ & 1.38 & $\begin{array}{c}0.26 \\
(0.15)\end{array}$ & 1.30 & $\begin{array}{c}0.18 \\
(0.15)\end{array}$ & 1.20 \\
\hline NatBio & $\begin{array}{l}0.57 * * * \\
(0.10)\end{array}$ & 1.77 & $\begin{array}{l}0.38 * * \\
(0.14)\end{array}$ & 1.46 & $\begin{array}{c}0.32 * \\
(0.15)\end{array}$ & 1.38 & $\begin{array}{c}0.17 \\
(0.15)\end{array}$ & 1.19 \\
\hline EnginPhys & $\begin{array}{l}1.07 * * * \\
(0.09)\end{array}$ & 2.92 & $\begin{array}{l}0.86^{* * *} \\
(0.12)\end{array}$ & 2.36 & $\begin{array}{l}0.76^{* * *} \\
(0.13)\end{array}$ & 2.14 & $\begin{array}{l}0.60 * * * \\
(0.13)\end{array}$ & 1.82 \\
\hline EdProf & $\begin{array}{l}0.38 * * * \\
(0.11)\end{array}$ & 1.46 & $\begin{array}{c}0.31 * \\
(0.14) \\
\end{array}$ & 1.36 & $\begin{array}{c}0.26 \\
(0.14) \\
\end{array}$ & 1.30 & $\begin{array}{c}0.20 \\
(0.14) \\
\end{array}$ & 1.22 \\
\hline Male*SocAppH & & & $\begin{array}{l}0.43^{*} \\
(0.21)\end{array}$ & 1.54 & $\begin{array}{l}0.43^{*} \\
(0.21)\end{array}$ & 1.54 & $\begin{array}{c}0.50^{*} \\
(0.21)\end{array}$ & 1.65 \\
\hline Male*NatBio & & & $\begin{array}{c}0.40 \\
(0.20)\end{array}$ & 1.49 & $\begin{array}{c}0.31 \\
(0.21)\end{array}$ & 1.36 & $\begin{array}{c}0.40 \\
(0.21)\end{array}$ & 1.49 \\
\hline Male*EnginPhys & & & $\begin{array}{c}0.41^{*} \\
(0.18)\end{array}$ & 1.51 & $\begin{array}{c}0.34 \\
(0.18)\end{array}$ & 1.40 & $\begin{array}{c}0.39 * \\
(0.18)\end{array}$ & 1.48 \\
\hline Male*EdProf & & & $\begin{array}{c}0.09 \\
(0.23) \\
\end{array}$ & 1.09 & $\begin{array}{c}0.04 \\
(0.23) \\
\end{array}$ & 1.04 & $\begin{array}{c}0.12 \\
(0.23) \\
\end{array}$ & 1.13 \\
\hline Satisf_Advisor & & & & & $\begin{array}{c}0.02 \\
(0.02)\end{array}$ & 1.02 & $\begin{array}{l}-0.03 \\
(0.02)\end{array}$ & 0.97 \\
\hline Career_Prep & & & & & $\begin{array}{l}0.14 * * * \\
(0.03)\end{array}$ & 1.15 & $\begin{array}{l}0.10 * * * \\
(0.03)\end{array}$ & 1.11 \\
\hline TA & & & & & $\begin{array}{l}-0.02 \\
(0.06)\end{array}$ & 0.98 & $\begin{array}{c}0.01 \\
(0.06)\end{array}$ & 1.01 \\
\hline RA & & & & & $\begin{array}{l}0.34 * * * \\
(0.08)\end{array}$ & 1.40 & $\begin{array}{l}0.31 * * * \\
(0.08)\end{array}$ & 1.36 \\
\hline Enc_Publication & & & & & & & $\begin{array}{l}0.11 * * * \\
(0.02)\end{array}$ & 1.12 \\
\hline Obstacle_Teaching & & & & & & & $\begin{array}{l}-0.09 * * \\
(0.03)\end{array}$ & 0.91 \\
\hline Obstacle_Family & & & & & & & $\begin{array}{l}-0.10^{* *} \\
(0.03)\end{array}$ & 0.90 \\
\hline Obstacle_Climate & & & & & & & 0.03 & 1.03 \\
\hline
\end{tabular}


Obstacle_Work

Obstacle_FacultyAvail

\begin{tabular}{lllllllll}
\hline \multirow{2}{*}{ Intercept } & $\begin{array}{l}0.73^{* * *} \\
(0.09)\end{array}$ & 2.08 & $\begin{array}{l}0.89^{* * *} \\
(0.11)\end{array}$ & 2.44 & $\begin{array}{c}0.70^{* * *} \\
(0.13)\end{array}$ & 2.01 & $\begin{array}{c}0.81^{* * *} \\
(0.14)\end{array}$ & 2.26 \\
\hline
\end{tabular}

Omnibus Test for

Interaction

$\chi^{2}(4)=8.58$

$\chi^{2}(4)=7.56$

$\chi^{2}(4)=8.48$

Coefficients $^{\mathrm{a}}$

$* p<.05, * * p<.01, * * * p<.001$

${ }^{a} \mathrm{~A}$ chi-squared test was used to determine if any of the interaction coefficients differed significantly from zero $\left(\mathrm{H}_{0}\right.$ : Male $* \mathrm{SocAppH}=$ Male*NatBio $=$ Male $*$ EnginPhys $=$ Male*EdProf $=0)$.

Note. See Table A5 note for details on how to interpret these Poisson regression results. The sample used in these analyses include only the subsample of students who responded to all of the variables included in Model 3. As noted above. only students who responded to the exit survey responded to the faculty encouragement of publication and obstacle variables included here. The variable pertaining to advisor support for chosen career path (from Table A3) was excluded from this analysis, as it was the only variable with no sex difference (overall or within any program). Likert scale items (Satisf_Advisor, Career_Prep, Enc_Publication) and all obstacle items were grand-mean centered for ease of interpretation. 
Running Head: SEX DIFFERENCES IN DOCTORAL PUBLICATIONS

Table A8

Correlations Among Main Survey Variables Included in Regression (from Table A5, $n=1,285$ )

\begin{tabular}{lcccc}
\hline & Satisf_Advisor & Career_Prep & RA & TA \\
\hline Satisf_Advisor & 1 & $.435^{* *}$ & .002 & $-.062^{*}$ \\
Career_Prep & $.435^{* *}$ & 1 & .054 & $-.068^{*}$ \\
RA & .002 & .540 & 1 & $.154^{* *}$ \\
TA & $-.062^{*}$ & $-.068^{*}$ & $.154^{* *}$ & 1 \\
${ }^{*} p<.05,{ }^{* *} p<.01,{ }^{* * *} p<.001$ & & &
\end{tabular}


Running Head: SEX DIFFERENCES IN DOCTORAL PUBLICATIONS

Table A9

Correlations Among Survey Variables in Subsample (from Table A7, $n=495$ )

\begin{tabular}{|c|c|c|c|c|c|c|c|c|c|c|}
\hline & $\begin{array}{l}\text { Satis } \\
\text { Advisor }\end{array}$ & $\begin{array}{c}\text { Career } \\
\text { Prep }\end{array}$ & RA & TA & $\begin{array}{c}\text { Enc- } \\
\text { Publicatio } \\
n\end{array}$ & $\begin{array}{l}\text { Obstacle } \\
\text { Work }\end{array}$ & $\begin{array}{l}\text { Obstacle } \\
\text { Teaching }\end{array}$ & $\begin{array}{c}\text { Obstacle } \\
\text { Family }\end{array}$ & $\begin{array}{c}\text { Obstacle_- } \\
\text { FacultyAvai } \\
1\end{array}$ & $\begin{array}{l}\text { Obstacle } \\
\text { Climate }\end{array}$ \\
\hline $\begin{array}{l}\text { Satis } \\
\text { Advisor }\end{array}$ & 1 & $.406 * *$ & $.041 * *$ & -.069 & $.334 * *$ & -.008 & $-.126^{* *}$ & -.009 & $-.344 * *$ & $-.165 * *$ \\
\hline Career_Prep & $.406 * *$ & 1 & $.110^{*}$ & -.067 & $.413 * *$ & $-.112 *$ & $-.139 * *$ & -.016 & $-.205 * *$ & $-.272 * *$ \\
\hline RA & .041 & $.110^{*}$ & 1 & .075 & $.151 * *$ & $-.158 * *$ & $-.094 *$ & -.087 & $-.105 *$ & -.081 \\
\hline TA & -.069 & -.067 & .075 & 1 & -.001 & .059 & $.212 * *$ & -.062 & .072 & .020 \\
\hline $\begin{array}{l}\text { Enc } \\
\text { Publication }\end{array}$ & $.334 * *$ & $.413 * *$ & $.151 * *$ & -.001 & 1 & $-.204 * *$ & $-.169 * *$ & $-.123 * *$ & $-.284 * *$ & $-.235^{* *}$ \\
\hline $\begin{array}{l}\text { Obstacle_ } \\
\text { Work }\end{array}$ & -.008 & $-.112 *$ & $-.158 * *$ & .059 & $-.204 * *$ & 1 & $.301 * *$ & $.213^{* *}$ & $.178 * *$ & $.274 * *$ \\
\hline $\begin{array}{l}\text { Obstacle_ } \\
\text { Teaching }\end{array}$ & $-.126 * *$ & $-.139 * *$ & $-.094 *$ & $.212 * *$ & $-.169 * *$ & $.301 * *$ & 1 & $.110^{*}$ & $.128 * *$ & $.136^{* *}$ \\
\hline $\begin{array}{l}\text { Obstacle_ } \\
\text { Family } \\
\text { Obstacle }\end{array}$ & -.009 & -.016 & -.087 & -.062 & $-.123 * *$ & $.213 * *$ & $.110^{*}$ & 1 & .087 & $.127 * *$ \\
\hline $\begin{array}{l}\text { FacultyAvai } \\
1\end{array}$ & $-.344 * *$ & $-.205^{* *}$ & $-.105^{*}$ & .072 & $-.284 * *$ & $.178 * *$ & $.128 * *$ & .087 & 1 & $.225 * *$ \\
\hline $\begin{array}{l}\text { Obstacle_ } \\
\text { Climate }\end{array}$ & $-.165 * *$ & $-.272 * *$ & -.081 & .020 & $-.235^{* *}$ & $.274 * *$ & $.136^{* *}$ & $.127 * *$ & $.225 * *$ & 1 \\
\hline
\end{tabular}

